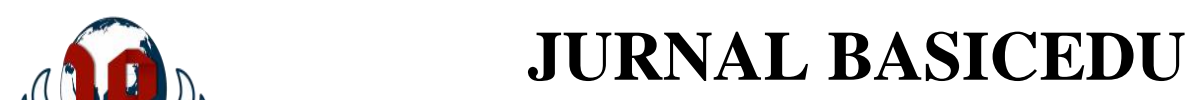

Volume 5 Nomor 3 Tahun 2021 Halaman 1652 - 1657

Research \& Learning in Elementary Education

https://jbasic.org/index.php/basicedu

PAHLAWAN

\title{
Penggunaan Media Audiovisual Berbantu Power Point untuk Meningkatkan Hasil Belajar Peserta Didik di Sekolah Dasar
}

\author{
Andina Widhayanti ${ }^{1 凶}$, Muhammad Abduh ${ }^{2}$ \\ Pendidikan Profesi Guru, Universitas Muhammadiyah Surakarta, Indonesia ${ }^{1,2}$ \\ E-mail: andinawidh69@gmail.com ${ }^{1}, \underline{\text { ma123@ums.ac.id }}{ }^{2}$
}

\begin{abstract}
Abstrak
Kesulitan dalam mengikuti dan memahami materi IPS kelas IV serta kurang optimalnya pemanfaatan media pembelajaran berbasis teknologi oleh guru menyebabkan peserta didik kurang antusias bertanya jawab dan pasif dalam diskusi saat pembelajaran. Tujuan penelitian yang ingin dicapai yaitu meningkatkan hasil belajar IPS melalui media audiovisual berbantuan power point. Jenis penelitian ini adalah penelitian tindakan kelas dengan analisis data kualitatif. Teknik pengumpulan data pada penelitian ini adalah observasi dan tes. Hasil penelitian ini menunjukkan bahwa hasil hasil belajar kognitif peserta didik melebihi kriteria ketuntasan minimal yaitu 70, dari 10 peserta didik yang mencapai KKM pada pra siklus dengan persentase $42 \%$ menjadi 17 peserta didik yang mencapai ketuntasan karena sudah sama atau melebihi KKM pada siklus I dengan persentase $71 \%$ dan menjadi 20 peserta didik yang mencapai ketuntasan melebihi KKM dengan persentase 83\% dari 24 peserta didik kelas IV. Hal ini berarti melalui media audiovisual berbantuan power point dapat meningkatkan hasil belajar peserta didik kelas IV SD Negeri Wonobodro 01 Tahun Pelajaran 2020/2021. Peserta didik tertarik mengikuti pembelajaran dan berusaha memperoleh nilai yang terbaik.
\end{abstract}

Kata Kunci: media audiovisual, power point, hasil belajar.

\begin{abstract}
Difficulty in following and understanding social studies material for grade IV and the less optimal use of technology-based learning media by teachers which causes students to be less enthusiastic about asking and answering questions and passively in discussions during learning. The research objective to be achieved is to improve social studies learning outcomes by audiovisual media with power points. This type of research is a classroom action with qualitative data analysis. The data research techniques in this study are observation and tests. The results of this study indicate that the learning outcomes of students exceed the minimum completeness criteria of 70, from 10 students who reached the minimum completeness criteria in the pre-cycle with a proportion of $42 \%$ to 17 students who achieved completeness because they are the same or exceeded the minimum completeness criteria in cycle I with a proportion of $71 \%$ to 20 students who achieved completeness beyond the minimum completeness criteria with a proportion of $83 \%$ of the 24 class IV students. This means that by audiovisual media with power points can improve learning outcomes for fourth grade students of SD Negeri Wonobodro 01 Academic Year 2020/2021. Students are interested in taking part in learning and trying to get the best value.
\end{abstract}

Keywords: audiovisual media, power points, learning outcomes

Copyright (c) 2021 Andina Widhayanti, Muhammad Abduh

Corresponding author:

Email : andinawidh69@gmail.com

DOI : https://doi.org/10.31004/basicedu.v5i3.975

ISSN 2580-3735 (Media Cetak)

ISSN 2580-1147 (Media Online)

Jurnal Basicedu Vol 5 No 3 Tahun 2021

p-ISSN 2580-3735 e-ISSN 2580-1147 
1653 Penggunaan Media Audiovisual Berbantu Power Point untuk Meningkatkan Hasil Belajar Peserta Didik di Sekolah Dasar - Andina Widhayanti, Muhammad Abduh

DOI: https://doi.org/10.31004/basicedu.v5i3.975

\section{PENDAHULUAN}

Pendidikan nasional yang berdasar pada Pancasila dengan tujuan untuk meningkatkan kualitas manusia di Indonesia, yaitu manusia yang beriman dan bertaqwa terhadap Tuhan Yang Maha Esa, berkepribadian, berbudi pekerti luhur, disiplin, bekerja keras, bertanggungjawab, cerdas, mandiri, terampil serta sehat jasmani dan rohani. Pendidikan nasional juga harus mampu menumbuhkan dan memperdalam rasa cinta terhadap tanah air, menambah semangat kebangsaan dan rasa kesetiakawanan sosial.

Ilmu pengetahuan di transfer oleh pendidik melalui proses pembelajaran yang dilakukan secara sadar dan terencana untuk membuat peserta didik belajar, sehingga pada diri peserta didik terjadi perubahan, yaitu perubahan tingkah laku. Adanya perubahan tersebut, maka peserta didik akan mendapat kemampuan baru yang berlaku dalam kurun waktu relatif lama (Anurrahman, 2013: 31). Seorang pendidik haruslah mampu menyiapkan peserta didik menjadi pribadi yang mandiri, mampu menggunakan dan mengembangkan sendiri kemampuan (pengetahuan serta keterampilann) yang telah dimilikinya, dan mempunyai sikap yang sesuai dengan norma-norma yang berlaku di masyarakat.

Dewasa ini, perkembangan teknologi berjalan dengan sangat cepat, semua aspek kehidupan menggunakan teknologi sebagai penunjangnya. Terutama pada bidang pendidikan, seorang pendidik harus mampu menggunakan teknologi dengan andal, dalam bentuk media pembelajaran yang digunakan dalam proses pembelajaran. Media pembelajaran merupakan sarana yang memungkinkan terwujudnya hubungan langsung antara karya seorang pendidik dengan peserta didik (Vannisa Aviana Melinda, I Nyoman Sudana Degeng 2017).

Media pembelajaran merupakan alat untuk membantu memperlancar komunikasi antara pendidik dan peserta didik sehingga proses pembelajaran berjalan efektif dan berhasil (Susanto, 2014: 315) dengan memperjelas makna pesan sehingga dapat mencapai tujuan pembelajaran (Kustandi, Cecep, 2011: 7). Pendidik dituntut untuk kreatif dalam menentukan media pembelajaran yang sesuai dengan peserta didik sehingga materi muatan pelajaran yang disampaikan dapat dipahami dengan dengan maksimal. Oleh karena itu, pada jenjang sekolah dasar dibutuhkan media penunjang untuk membantu proses pembelajaran supaya berjalan dengan menyenangkan dan menarik minat belajar peserta didik.

Muatan pelajaran di sekolah dasar, salah satunya adalah IPS. IPS melibatkan berbagai cabang-cabang ilmu-ilmu sosial dan humaniora (Mukminan, 2017: 2) seperti sejarah, geografi, ekonomi, sosiologi, dan antropologi. Perpaduan tersebut dimaksudkan untuk membiasakan peserta didik sejak usia sekolah dasar dalam memecahkan masalah sosial dengan pendekatan secara utuh tidak terkotak-kotak dari berbagai disiplin ilmu sosial (Vannisa Aviana Melinda, I Nyoman Sudana Degeng 2017). Supaya peserta didik mampu berinteraksi dan memberikan kontribusi dalam lingkungan sosial dengan mengembangkan pengetahuan dan keterampilan dasar yang berguna bagi dirinya. Untuk itu, pembelajaran IPS harus menekankan pada nilai, sikap, pengetahuan dan kemampuan analisis peserta didik sebelum memasuki kehidupan masyarakat yang dinamis (Supriyanti, 2019: 239).

Berdasarkan observasi peneliti, proses pembelajaran pada muatan pelajaran IPS di kelas IV SD Negeri Wonobodro 01 masih belum maksimal. Interaksi peserta didik yang kurang dengan guru menyebabkan kurang antusias dalam kegiatan tanya jawab dan bersikap pasif saat diskusi. Guru kelas IV terkait dengan proses pembelajaran didapati bahwa guru belum mengoptimalkan penggunaan media pembelajaran sehingga peserta didik sulit mengikuti dan memahami materi muatan pelajaran IPS. Penggunaan media pembelajaran yang tepat di dalam pembelajaran mampu menunjang keberhasilan guru dan peserta didik. Berdasarkan hasil tersebut, peneliti menawarkan solusi dengan menggunakan media audiovisual berbantuan power point supaya peserta didik antusias mengikuti pembelajaran dan meningkatkan hasil belajar sesuai target yang diinginkan.

Power point adalah media yang sering dijumpai dan sering pula digunakan dalam berbagai kesempatan entah itu dalam presentasi, seminar, maupun proses pembelajaran. Microsoft Power Point merupakan program 
1654 Penggunaan Media Audiovisual Berbantu Power Point untuk Meningkatkan Hasil Belajar Peserta Didik di Sekolah Dasar - Andina Widhayanti, Muhammad Abduh

DOI: https://doi.org/10.31004/basicedu.v5i3.975

presentasi yang di kembangkan oleh Microsoft Office dan di tampilkan ke layar mengunakan bantuan LCD proyektor (Hujair, 2013: 135) yang dapat digunakan untuk persentasi taupun media pembelajaran di sekolah. Media ini mampu menggabungkan antara audio dan visual. Media audiovisual mampu menyalurkan pesan dengan memanfaatkan indera pendengaran dan indera penglihatan (Sukiman, 2012: 184). Media audiovisual dapat digunakan untuk menyampaikan pesan melalui kegiatan mendengar dan melihat sehingga jika power point digunakan pada proses pembelajaran akan membuat peserta didik tertarik, dan mampu meningkatkan kualitas pembelajaran, yang diharapkan nantinya hasil belajar lebih meningkat. Selaras dengan hasil penelitian Isnaeni (2021) bahwa penggunaan media audiovisual menunjukkan pengaruh yaitu adanya peningkatan hasil belajar IPS peserta didik dengan rata-rata yang signifikan sebesar 37,96\%.

Hasil belajar adalah hasil yang diperoleh seseorang berupa kesan-kesan yang mengakibatkan perubahan dalam diri sebagai hasil dari aktivitas belajar (Djamarah, Syaiful Bahri, 2015: 23). Hasil belajar merupakan akuisisi pengetahuan, sikap dan keterampilan dalam bentuk skor angka yang diperoleh pada tes oleh subjek tertentu (Juandi \& Sontani, 2017: 244). Hasil belajar dapat dijadikan untuk mengetahui, memahami dan menunjukkan keberhasilan yang sudah dicapai atau diperoleh peserta didik dalam proses belajar. Proses pembelajaran IPS dengan menggunakan media audiovisual berbantuan power point supaya penyampaian materi lebih maksimal dan peserta didik mampu mengetahui, memahami dan bersikap sesuai dengan materi yang ditampilkan pada slide power point.

\section{METODE PENELITIAN}

Penelitian ini menggunakan penelitian tindakan kelas. Penelitian tindakan kelas adalah tindakan yang dilakakukan guru untuk merancang pemecahan masalah yang dihadapi dalam kelas (Sutama, 2011: 134) yang bertujuan untuk memperbaiki proses belajar mengajar (Kunandar, 2013: 45). Proses penelitian dicirikan dengan adanya tindakan dalam suatu siklus. Jika suatu siklus belum mengalami perubahan maka akan dilaksanakan siklus selanjutnya sampai permasalahan bisa terselesaikan. Penelitian tindakan kelas terdiri dari tahap perencanaa, pelaksanaan tindakan, pengamatan dan refleksi (Kusumah, Dwitagama, 2012: 21)

Pengumpulan data dalam penelitian ini menggunakan observasi dan tes. Observasi dilakukan untuk menyajikan gambaran proses belajar peserta didik. Tes berisi sejumlah pertanyaan yang yang membutuhkan tanggapan sebagai jawaban untuk mengukur tingkat kemampuan pengetahuan (Widoyoko, 2014: 50) peserta didik dalam muatan pelajaran IPS pada materi sumber daya alam. Validitas data yang menggunakan triangulasi teknik atau metode dengan analisis data deskritif kualitatif melalui tahapan reduksi, data display serta menarik kesimpulan (Emzir, 2016: 129).

Penelitian dilaksanakan di kelas IV SDN Wonobodro 01 pada pembelajaran muatan IPS. Lokasi sekolah berada di desa Wonobodro kecamatan Baldo kabupaten Batang. Subyek penelitian adalah 24 peserta didik yang terdiri dari 12 peserta didik perempuan dan 12 peserta didik laki-laki.

\section{HASIL DAN PEMBAHASAN}

Hasil penelitian menunjukkan bahwa media audiovisual berbantuan power point pada kelas IV SD Negeri Wonobodro 01 dalam muatan pelajaran IPS mengalami peningkatan hasil belajar peserta didik di setiap siklusnya. Hasil belajar meliputi aspek kognitif, afektif dan psikomotor. Dalam hal ini peneliti mengambil fokus pada hasil belajar kognitif. Informasi awal mengenai hasil belajar kogntif peserta didik dapat dilihat dari data hasil pretest siswa dengan KKM sebesar 70, maka diperoleh rata-rata nilai peserta didik adalah 53. Peserta didik yang mencapai ketuntasan ada 10 orang (42\%) dan 14 peserta didik yang belum mencapai nilai ketuntasan. 
1655 Penggunaan Media Audiovisual Berbantu Power Point untuk Meningkatkan Hasil Belajar Peserta Didik di Sekolah Dasar - Andina Widhayanti, Muhammad Abduh

DOI: https://doi.org/10.31004/basicedu.v5i3.975

Setelah itu dilaksanakan tindakan siklus I. Hasil belajar IPS peserta didik pada siklus I ini diperoleh rata-rata nilai 71 dengan 17 peserta didik yang mencapai ketuntasan dan 7 peserta didik belum mencapai ketuntasan dengan persentase sebesar 71\%. Meskipun sudah mengalami peningkatan dari kondisi sebelumnya, tetapi persentase belum maksimal. Pada siklus II dilaksanakan perbaikan tindakan dan memperoleh rata-rata nilai hasil belajar sebesar 83 dengan 20 peserta didik yang mencapai ketuntasan dan 4 peserta didik belum mencapai ketuntasan dengan persentase sebesar 83\%. Hal tersebut telah mencapai indikator pencapaian penelitian yang telah ditetapkan dengan persentase ketuntasan $\geq 80 \%$ dengan KKM 70 .

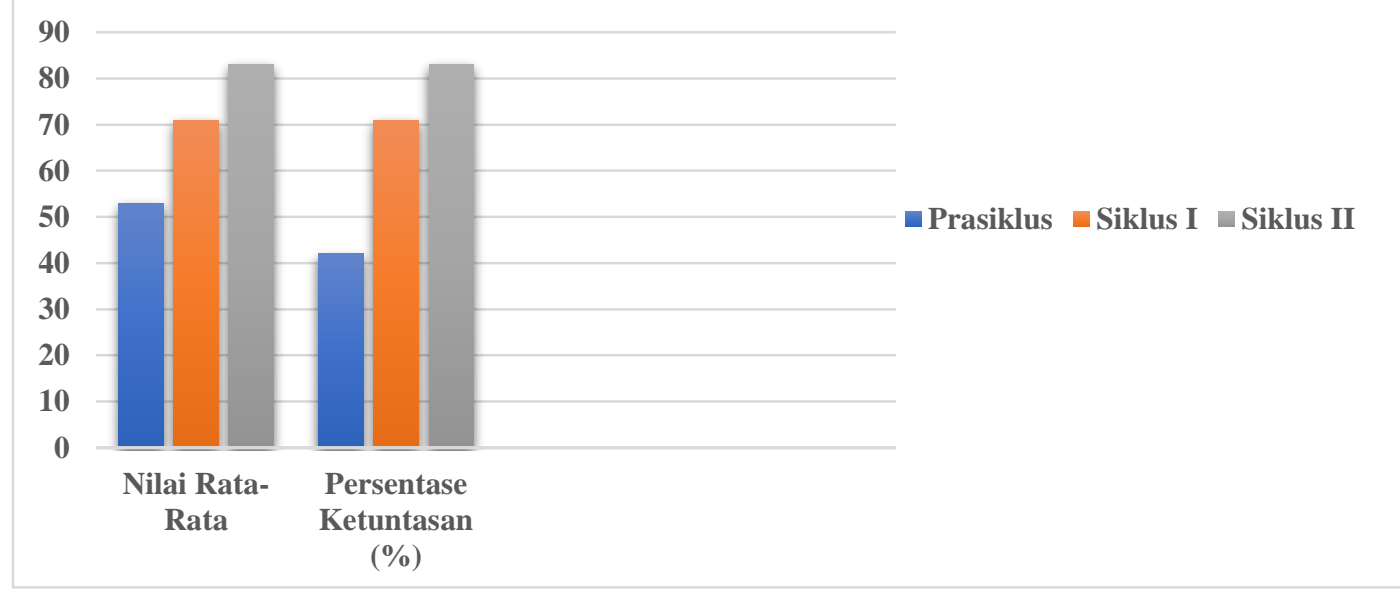

Diagaram 1. Grafik peningkatan hasil belajar IPS peserta didik kelas IV

Berdasarkan hasil di atas, peserta didik berusaha yakin memperoleh nilai terbaik, hal tersebut terlihat dari peningkatan hasil belajar kognitif dari setiap siklusnya. Proses pembelajaran dilaksanakan dengan menerapakan media audiovisual sehingga peserta didik mampu memahami materi dari penjelasan guru dan gambar visual pada slide power point. Slide power point mampu membantu mempresentasikan pesan yang disampaikan guru kepada peserta didik karena dapat ditangkap oleh indera penglihatan dan pendengaran dengan rangsangan-rangsangan multimedia berupa teks, audio, visual, dan video (Muthoharoh, 2019: 24). Media pembelajaran yang digunakan guru mampu membangun interaksi yang baik sehingga dalam proses pembelajaran menjadi menarik dan menyenangkan. Peserta didik aktif berpendapat, bertanya dan menjawab pertanyaan saat proses pembelajaran. Hal ini menunjukkan peningkatan partisipasi peserta didik dengan penggunaan media audiovisual dalam belajar (Hendrawan, 2017: 611). Nilai rata-rata kelas pada muatan pelajaran IPS meningkat seiring dengan ketekunan peserta didik mengumpulkan tugas tepat waktu. Keinginan peserta didik untuk memperoleh nilai yang tinggi mampu meningkatkan persentase ketuntasan minimal mencapai $83 \%$. Penelitian ini dapat disimpulkan bahwa menggunakan media audiovisual berbantuan power point mampu meningkatkan hasil belajar peserta didik kelas IV SD Negeri Wonobodro 01 Tahun pelajaran 2020/2021. Media auidovisual berbantu power point mampu menjelaskan materi muatan pelajaran IPS secara maksimal karena menampilkan gambar visual, teks penjelas dan suara sehingga aspek pengetahuan yang telah dirumuskan dalam tujuan pembelajaran dapat tercapai (Riswanto and Aryani, 2017:43)

Penelitian yang serupa oleh Mutmainnah (2018) menerangkan bahwa dengan penggunaan media power point dapat meningkatkan hasil belajar siswa karena mampu membuat siswa menjadi paham dan menguasai materi. Senada dengan Tang \& Intai (2018) menerangkan bahwa alat bantu audio visual efektif dalam meningkatkan pemahaman siswa yang ditunjukkan dengan peningkatan nilai yang signifikan. Siswa lebih perhatian pada saat alat bantu audio visual dimainkan. Penggunaan alat bantu audio visual meningkatkan minat dan kemampuan siswa dalam mengingat materi pelajaran. 
1656 Penggunaan Media Audiovisual Berbantu Power Point untuk Meningkatkan Hasil Belajar Peserta Didik di Sekolah Dasar - Andina Widhayanti, Muhammad Abduh

DOI: https://doi.org/10.31004/basicedu.v5i3.975

\section{KESIMPULAN}

Penggunaan media audiovisual berbantuan power point dapat meningkatkan hasil belajar peserta didik kelas IV SD Negeri Wonobodro 01 Tahun Pelajaran 2020/2021. Hasil belajar kognitif peserta didik yang melebihi kriteria ketuntasan minimal yakni 70, dari 10 peserta didik yang mencapai KKM pada pra siklus menjadi 17 peserta didik yang mencapai ketuntasan karena sudah sama atau melebihi KKM pada siklus I dan menjadi 20 peserta didik yang mencapai ketuntasan melebihi KKM dari 24 peserta didik. Peserta didik yang belum mencapai ketuntasan mendapatkan bimbingan dari guru dan mendapatkan remidial. Setelah diterapkannya media audiovisual berbantuan power point menunjukkan bahwa terdapat peningkatan hasil belajar IPS peserta didik.

\section{UCAPAN TERIMAKASIH}

Tulisan ini dilaksanakan untuk melakukan perbaikan permasalahan dalam kelas IV di SD Negeri Wonobodro 01. Oleh karena itu, penulis mengucapkan terima kasih kepada dosen pembimbing Muhammad Abduh, M. Pd., kepala sekolah, guru dan siswa serta semua yang membantu.

\section{DAFTAR PUSTAKA}

Anurrahman. 2013. Belajar Dan Pembelajaran. Bandung: Alfa Beta.

Djamarah, Syaiful Bahri. 2015. Psikologi Belajar. Jakarta: Rineka Cipta.

Emzir. 2016. Metodologi Penelitian Kualitatif: Analisis Data. Jakarta: PT Grafindo Persada.

Hendrawan, Wiwin. 2017. "Upaya Meningkatkan Hasil Belajar Ips Melalui Penggunaan Media Audio-Visual Pada Siswa Kelas Ivb Sd Negeri I Blunyahan.” Jurnal Pendidikan Guru Sekolah Dasar 6(6): 611-18.

Hujair, Sanaki. 2013. Media Pembelajaran Interaktif Inovatif. Yogyakarta: Kaukaba.

Isnaeni, Rosalia et al. 2021. "EDUKATIF: JURNAL ILMU PENDIDIKAN Meta-Analisis Pengaruh Penggunaan Media Audio Visual Terhadap Hasil Belajar IPS Siswa Di Sekolah Dasar Abstrak." 3(2): $304-13$.

Juandi, Acep, and Uep Tatang Sontani. 2017. "Keterampilan Dan Kreativitas Mengajar Guru Sebagai Determinan Terhadap Prestasi Belajar Siswa." Jurnal Pendidikan Manajemen Perkantoran 2(2): 130.

Kunandar. 2013. Langkah Mudah Penelitian Tindakan Kelas. Jakarta: PT Grafindo Persada.

Kustandi, Cecep, Sutjipto Bambang. 2011. Media Pembelajaran Manual Dan Digital. Bogor: Galia Indonesia.

Kusumah, Dwitagama, W. 2012. Mengenal Penelitian Tindakan Kelas. Jakarta: Index.

Mukminan, Edy Surahman. 2017. "PERAN GURU IPS SEBAGAI PENDIDIK DAN PENGAJAR DALAM MENINGKATKAN SIKAP SOSIAL DAN TANGGUNG JAWAB SOSIAL SISWA SMP." Harmoni Sosial 4(1): 1-13. http://journal.uny.ac.id/index.php/hsjpi.

Muthoharoh, Miftakhul. 2019. "Media PowerPoint Dalam Pembelajaran.” Tasyri 2(1): 21-32.

Mutmainnah. 2018. "Penggunaan Media Pembelajaran Power Point Untuk Sekolah Dasar." Jurnal Teknologi Pendidikan dan Pembelajaran 5(2): 123-30.

Riswanto, Ari, and Sri Aryani. 2017. "Learning Motivation and Student Achievement: Description Analysis and Relationships Both." COUNS-EDU: The International Journal of Counseling and Education 2(1): 42 .

Sukiman. 2012. Pengembangan Media Pembelajaran. Yogyakarta: PT Pustaka Insan Madani. 
1657 Penggunaan Media Audiovisual Berbantu Power Point untuk Meningkatkan Hasil Belajar Peserta Didik di Sekolah Dasar - Andina Widhayanti, Muhammad Abduh

DOI: https://doi.org/10.31004/basicedu.v5i3.975

Susanto, Ahmad. 2014. Pengembangan Pembelajaran IPS Di Sekolah Dasar. Jakarta: Prenada Media Group.

Sutama. 2011. Metode Penelitian Pendidikan. Surakarta: Fairuz Media.

Syupriyanti, Lisa. 2019. "Pengaruh Media Audio Visual Interaktif Menggunakan Pendekatan CTL Dalam Pembelajaran Tematik Terpadu Terhadap Hasil Belajar Dan Motivasi Siswa Di Sekolah Dasar." Jurnal Ilmu Pendidikan 1(3): 273-243.

Tang, Daniel Kuok Ho, and Rangis Intai. 2018. "Effectiveness of Audio-Visual Aids in Teaching Lower Secondary Science in A Rural Secondary School." Asia Pacific Journal of Educators and Education 32: 91-106.

Vannisa Aviana Melinda, I Nyoman Sudana Degeng, Dedi Kuswandi. 2017. "Pengembangan Media Video Pembelajaran Ips Berbasis Virtual Field Trip (Vft) Pada Kelas V Sdnu Kraton-Kencong." JINOTEP (Jurnal Inovasi dan Teknologi Pembelajaran) Kajian dan Riset dalam Teknologi Pembelajaran 3(2): 158-64. http://journal2.um.ac.id/index.php/jinotep/article/download/2383/1435.

Widoyoko, E. 2014. Evaluasi Program Pembelajaran. Yogyakarta: Pustaka Pelajar. 